\title{
Zooplankton Composition and Community Structure of Kottakudi and Nari Backwaters, South East of Tamil Nadu
}

\author{
K. Thirunavukkarasu ${ }^{1}$, P. Soundarapandian ${ }^{2 *}$, D. Varadharajan ${ }^{2}$ and B. Gunalan ${ }^{2}$ \\ ${ }^{1}$ Department of Advanced Zoology and Animal Biotechnology, Sree Sevugan Annamalai College, Devakottai, Tamil Nadu, India \\ ${ }^{2}$ Faculty of Marine Sciences, Centre of Advanced Study in Marine Biology, Annamalai University, Parangipettai-608 502, Tamil Nadu, India
}

\begin{abstract}
Zooplankton plays an important role to study the faunal bio-diversity of aquatic ecosystems. It is occurrence and distribution influences the fishery potentials. The fishes mostly breed in areas where the planktonic organisms are plenty so that their young ones could get sufficient food for survival and growth. The zooplankton composition during the study period includes the members of Foraminifera, Rotatoria, Calanoida, Cyclopoida, Harpacticoidea, Doliolida, Appendicularia, Decapoda, Sagittoida, Amphipoda, Coelentrata, Pteropoda, Cladocera and larval forms. In station I, about 88 species of zooplankton were recorded. In station II, about 92 species of zooplankton were recorded. The zooplankton population densities were ranged from 23,150 to $80,890 \mathrm{org} / \mathrm{l}$ in station I and 23,197 to $80,691 \mathrm{org} / \mathrm{l}$ in station II. The Shannon - Wiener's diversity index $\left(\mathrm{H}^{\prime}\right)$ values were ranged from 4,505 bits/ind. to 5,915 in station I and 4,590 bits/ind. to 5,928 bits/ind. in station II. The Simpson richness was ranged from 0.662 to 0.995 in station I and 0.665 to 0.998 in station II. The Pielou's evenness $\left(J^{\prime}\right)$ was ranged from 0.590 to 0.952 in station I and 0.513 to 0.952 in station II respectively.
\end{abstract}

Keywords: Zooplankton; Composition; Kottakudi; Nari backwaters; Research background

\section{Introduction}

Zooplanktons are the small, floating and weakly swimming animals found in various water bodies including coastal waters. Together with the phytoplankton and the bacterio-plankton, they constitute the plankton community. They assume a great ecological significance in the ecosystem as they play a vital role in food web of the food chain, nutrient recycling and transfer of organic matter from primary producers to secondary consumers like fishes [1-3]. Zooplankton help determines the quantum of fish stock and the failure of fishery resources is attributed to the reduced copepod population [4]. Hence, the zooplankton communities, based on their quality and species diversity, are used for assessing the productivity of fishery resources, fertility and health status of the ecosystem. Marine zooplankton comprises a large variety of different organisms with some ten thousands of species of mero-plankton. Their sizes range from tiny flagellates to giant jellyfish. The growth rate, productivity and species diversity of zooplankton in tropical waters especially in coastal waters is high. The zooplankton community is represented by heterogeneous groups of organisms of varying size and belonging to different phyla of animal kingdom. Over $70 \%$ of total zooplankton of coastal waters was constituted by primitive crustaceans belonging to the order, 'Copepoda' of the phylum, 'Arthropoda'. The order-Copepoda comprised of three sub-orders viz; Calanoida, Cyclopoida and Harpacticoida [2]. Any study concern with ecological community structure is dependent on accurate information on the distribution and abundance of the species making up the community [5].

Zooplankton is an inseparable part of the aquatic ecosystem, and it fulfills a great variety of important function as secondary producers. To species diversity indices of zooplankton communities are used to evaluate the quality of water. Hence, zooplankton can be used as an indicator of sorority. In addition, species diversity, abundance and biomass of zooplankton determine production of fish in the ecosystem [6]. In the present investigation an attempt has been made to investigate the species composition, population density and structure of zooplankton from Kottakudi and Nari backwaters.

\section{Materials and Methods}

Zooplankton samples were collected in monthly intervals from the stations I- Kottakudi and station II- Nari backwaters for a period of two years from January 2010 to December 2011. The samples were collected by horizontal towing of plankton net $(0.35 \mathrm{~m}$ mouth diameter), made up of bolting silk (Cloth No.10; mesh size $158 \mu \mathrm{m}$ ) for twenty minutes at one knot speed. These samples were preserved in new polythene container with 5\% neutralized formalin and used for qualitative analysis. For the quantitative analysis of zooplankton a known quantity of water (1000 liters) was filtered through a bag-net of same mesh size and the numerical plankton analysis was carried out using a binocular microscope. The zooplanktons were qualitatively identified using the standard works of Davis [7], Kasturirangan [8], Newell and Newell [9], Deboyd L Smith [10], Wimpenny [11], Todd [12], Perumal et al. [13]. The isolated zooplanktons were subjected to species composition and population density. The statistical analysis such as species diversity was calculated using diversity $\left(\mathrm{H}^{\prime}\right)$ Index [14]; species richness was calculated by following Simpson Index (D') formula and species evenness was calculated using the formula proposed by Pielous [15] as Pielou's Evenness (J') Index.

The Two way ANOVA test was employed to find out the variations in physico-chemical parameters, population density, species diversity, species richness and species evenness in relation to stations and

*Corresponding author: P. Soundarapandian, Faculty of Marine Sciences, Centre of Advanced Study in Marine Biology, Annamalai University, Parangipettai-608 502, Tamil Nadu, India, Tel: 04144-243223; Fax: 04144-243553; E-mail: soundsuma@ gmail.com

Received November 26, 2013; Accepted December 16, 2013; Published December 18, 2013

Citation: Thirunavukkarasu K, Soundarapandian P, Varadharajan D, Gunalan B (2013) Zooplankton Composition and Community Structure of Kottakudi and Nari Backwaters, South East of Tamil Nadu. J Environ Anal Toxicol 4: 200. doi: 10.4172/2161-0525.1000200

Copyright: (c) 2013 Thirunavukkarasu K, et al. This is an open-access article distributed under the terms of the Creative Commons Attribution License, which permits unrestricted use, distribution, and reproduction in any medium, provided the original author and source are credited. 
Citation: Thirunavukkarasu K, Soundarapandian P, Varadharajan D, Gunalan B (2013) Zooplankton Composition and Community Structure of Kottakudi and Nari Backwaters, South East of Tamil Nadu. J Environ Anal Toxicol 4: 200. doi: 10.4172/2161-0525.1000200

Page 2 of 7

months. Pearson-correlation coefficient analysis was performed between physico-chemical parameters and population density, species diversity, species richness and species evenness for both the stations.

\section{Results}

\section{Species composition}

The zooplankton composition during the study period includes the members of Foraminifera, Rotatoria, Calanoida, Cyclopoida, Harpacticoidea, Doliolida, Appendicularia, Decapoda, Sagittoida, Amphipoda, Coelentrata, Pteropoda, Cladocera and larval forms. In station I, about 88 species of zooplankton were recorded which includes 16 species of Foraminifera, 2 species of Rotatoria, 28 species of Calanoida, 6 species of Harpacticoidea, 6 species of Cyclopoida, 2 species of Doliolida, 2 species of Appendicularia, 1 species of Decapoda, 2 species of Sagittoida, 1 species of Amphipoda, 3 species of Coelentrata, 1 species of Pteropoda, 2 species of Cladocera and 16 species of larval forms. In station II, about 92 species of zooplankton were recorded which includes 17 species of Foraminifera, 2 species of Rotatoria, 31 species of Calanoida, 6 species of Harpacticoidea, 6 species of Cyclopoida, 2 species of Doliolida, 2 species of Appendicularia, 1 species of Decapoda, 2 species of Sagittoida, 1 species of Amphipoda, 3 species of Coelentrata, 1 species of Pteropoda, 2 species of Cladocera and 16 species of larval forms (Table 1 ).

\begin{tabular}{|c|c|c|c|c|c|}
\hline \multirow[t]{2}{*}{ S. No. } & \multirow[t]{2}{*}{ Name of the species } & \multicolumn{2}{|c|}{ Station I } & \multicolumn{2}{|c|}{ Station II } \\
\hline & & 2010 & 2011 & 2010 & 2011 \\
\hline & \multicolumn{5}{|l|}{ Foraminifera } \\
\hline & Globigerina rubescense & + & + & + & + \\
\hline & G. bulloides & + & + & + & + \\
\hline & G. opima & + & + & + & + \\
\hline & Tintinnopsis cylindrica & + & + & + & + \\
\hline & T. beroidea & + & + & + & + \\
\hline & T. butschi & + & + & + & + \\
\hline & T. tocantinensis & + & + & + & + \\
\hline & T. tubulosa & + & + & + & + \\
\hline & T. minuta & - & - & + & + \\
\hline & T. brindle & + & + & + & + \\
\hline & T. mortensenii & + & + & + & + \\
\hline & Eutintinnus tennuis & + & + & + & + \\
\hline & Dictyocysta seshaiyai & + & + & + & + \\
\hline & Codonellopsis ostenfeldii & + & + & + & + \\
\hline & Favella philipensis & + & + & + & + \\
\hline & F. brevis & + & + & + & + \\
\hline & Rhabdonella lohmanni & + & + & + & + \\
\hline & \multicolumn{5}{|l|}{ Rotatoria } \\
\hline & Brachionus calyciflorus & + & + & + & + \\
\hline & B. plicatilis & + & + & + & + \\
\hline & \multicolumn{5}{|l|}{ Calanoida } \\
\hline & Calanus sp. & + & + & + & + \\
\hline & Nannocalanus minor & + & + & + & + \\
\hline & Canthocalanus pauper & + & + & + & + \\
\hline & Eucalanus elongatus & + & + & + & + \\
\hline
\end{tabular}

\begin{tabular}{|c|c|c|c|c|}
\hline E. monachus & - & - & + & - \\
\hline Calanopia minor & + & + & + & + \\
\hline Metacalanus aurivilli & + & + & + & + \\
\hline Paracalanus parvus & + & + & + & + \\
\hline Acrocalanus gibber & + & + & + & + \\
\hline A. gracilis & + & + & + & + \\
\hline Centropages tenuiremis & + & + & + & + \\
\hline C. furcatus & + & + & + & + \\
\hline Pseudodiaptomus aurivilli & + & + & + & + \\
\hline P. serricaudatus & + & + & + & + \\
\hline Labidocera pavo & + & + & + & + \\
\hline L. acuta & - & - & + & - \\
\hline L. pectinata & + & + & + & + \\
\hline L. minuta & + & + & + & + \\
\hline Pontella sp. & + & + & + & + \\
\hline Pontella danae & + & + & + & + \\
\hline P. securifer & + & + & + & + \\
\hline Pontellopsis herdmani & + & + & + & + \\
\hline Acartia spinicauda & + & + & + & + \\
\hline A. southwelli & + & + & + & + \\
\hline A. erythraea & + & + & + & + \\
\hline A. danae & - & - & + & - \\
\hline A. centrura & + & + & + & + \\
\hline Tortanus barbatus & + & + & + & + \\
\hline Temora turbinata & + & + & + & + \\
\hline T. stylifera & + & + & + & + \\
\hline T. discaudata & + & + & + & + \\
\hline \multicolumn{5}{|l|}{ Harpacticoidea } \\
\hline Clytemnestra scutellata & + & + & + & + \\
\hline Euterpina acutifrons & + & + & + & + \\
\hline Microsetella rosea & + & + & + & + \\
\hline M. norvegica & + & + & + & + \\
\hline Macrosetella gracilis & + & + & + & + \\
\hline Metis jousseamei & + & + & + & + \\
\hline \multicolumn{5}{|l|}{ Cyclopoida } \\
\hline Oithona rigida & + & + & + & + \\
\hline O. brevicornis & + & + & + & + \\
\hline O. similis & + & + & + & + \\
\hline Oncaea venusta & + & + & + & + \\
\hline Corycaeus catus & + & + & + & + \\
\hline C. danae & + & + & + & + \\
\hline \multicolumn{5}{|l|}{ Doliolida } \\
\hline Doliolum coioides & + & + & + & + \\
\hline Salpa fusiformis & + & + & + & + \\
\hline \multicolumn{5}{|l|}{ Appendicularia } \\
\hline Oikopleura parva & + & + & + & + \\
\hline O. dioica & + & + & + & + \\
\hline Decapoda & & & & \\
\hline
\end{tabular}


Citation: Thirunavukkarasu K, Soundarapandian P, Varadharajan D, Gunalan B (2013) Zooplankton Composition and Community Structure of Kottakudi and Nari Backwaters, South East of Tamil Nadu. J Environ Anal Toxicol 4: 200. doi: 10.4172/2161-0525.1000200

Page 3 of 7

\begin{tabular}{|c|c|c|c|c|c|}
\hline & Lucifer hanseni & + & + & + & + \\
\hline & \multicolumn{5}{|l|}{ Sagittoida } \\
\hline & Sagitta enflata & + & + & + & + \\
\hline & S.bipunctata & + & + & + & + \\
\hline & \multicolumn{5}{|l|}{ Amphipoda } \\
\hline & Amphithoe sp. & + & + & + & + \\
\hline & \multicolumn{5}{|l|}{ Coelentrata } \\
\hline & Diphyes sp. & + & + & + & + \\
\hline & Obelia sp. & + & + & + & + \\
\hline & Aurelia sp. & + & + & + & + \\
\hline & \multicolumn{5}{|l|}{ Pteropoda } \\
\hline & Creseis sp. & + & + & + & + \\
\hline & \multicolumn{5}{|l|}{ Cladocera } \\
\hline & Penilia sp. & + & + & + & + \\
\hline & Evadne sp. & + & + & + & + \\
\hline & \multicolumn{5}{|l|}{ Larval forms } \\
\hline & Mysis larvae & + & + & + & + \\
\hline & Crustacean nauplius & + & + & + & + \\
\hline & Copepod naupliius & + & + & + & + \\
\hline & Barnacle nauplius & + & + & + & + \\
\hline & Shrimp zoea & + & + & + & + \\
\hline & Crab zoea & + & + & + & + \\
\hline & Euphasid zoea & + & + & + & + \\
\hline & Hydrozoan larvae & + & + & + & + \\
\hline & Acanthomentron & + & + & + & + \\
\hline & Gastropod veliger & + & + & + & + \\
\hline & Bivalve veliger & + & + & + & + \\
\hline & Polychaete larvae & + & + & + & + \\
\hline & Cyphonautes larvae & + & + & + & + \\
\hline & Ophiopluteus larvae & + & + & + & + \\
\hline & Fish larvae & + & + & + & + \\
\hline & Fish egg & + & + & + & + \\
\hline Total & & 88 & 88 & 92 & 89 \\
\hline
\end{tabular}

+ Present - Absent

Table 1: Check list of zooplankton species recorded from January 2010 to December 2011

\section{Population density}

The zooplankton population densities ranged from 23,150 to $80,890 \mathrm{org} / \mathrm{l}$ in station I and 23,197 to $80,691 \mathrm{org} / \mathrm{l}$ in station II. Minimum zooplankton population densities were recorded in the month of December (2010) and maximum in the month of June (2011) in station I. In station II, the zooplankton population densities were recorded minimum in the month of December (2010) and maximum in the month of June (2011) (Table 2). The population density showed significant variation between two stations (Table 3). Population density showed positive correlation with temperature, salinity and $\mathrm{pH}$ and showed negative correlation with rainfall in station I. Population density is positively correlated with temperature and negatively correlated with rainfall in station II (Tables 7 and 8).

\section{Shannon-Wiener's diversity $\left(\mathrm{H}^{\prime}\right)$}

The Shannon-Wiener's diversity index $\left(\mathrm{H}^{\prime}\right)$ values were ranged

\begin{tabular}{|c|c|c|c|c|c|}
\hline \multirow{2}{*}{ Seasons } & \multirow{2}{*}{ Months } & \multicolumn{2}{|c|}{2010} & \multicolumn{2}{c|}{2011} \\
\cline { 3 - 6 } & & Station I & Station II & Station I & Station II \\
\hline \multirow{3}{*}{ Post monsoon } & January & 50,980 & 50,195 & 50,290 & 50,315 \\
\cline { 2 - 6 } & February & 60,890 & 60,610 & 60,520 & 60,490 \\
\cline { 2 - 6 } & March & 70,639 & 70,410 & 70,390 & 70,410 \\
\hline \multirow{3}{*}{ Summer } & April & 78,191 & 78,210 & 78,119 & 78,290 \\
\cline { 2 - 6 } & May & 80,380 & 80,399 & 80,400 & 80,490 \\
\cline { 2 - 6 } & June & 80,890 & 80,630 & 80,730 & 80,691 \\
\hline \multirow{3}{*}{ Monsoon } & July & 41,150 & 41,610 & 41,992 & 41,680 \\
\cline { 2 - 6 } & August & 32,690 & 32,715 & 32,638 & 32,415 \\
\cline { 2 - 6 } & September & 31,198 & 31,215 & 31,128 & 31,125 \\
\cline { 2 - 6 } & October & 29,630 & 29,515 & 29,390 & 29,398 \\
\cline { 2 - 6 } & November & 27,615 & 27,390 & 27,615 & 27,415 \\
\cline { 2 - 6 } & December & 23,150 & 23,197 & 23,397 & 23,210 \\
\hline
\end{tabular}

Table 2: Monthly variations of zooplankton population density (org/l) from January 2010 to December 2011

\begin{tabular}{|c|c|c|c|c|c|c|}
\hline Source of Variation & SS & df & MS & F & F crit & $\mathbf{P}$ \\
\hline \multicolumn{7}{|l|}{ Population density } \\
\hline Stations & 27484020 & 1 & 27484020 & 22.64096 & 4.844336 & $<0.05$ \\
\hline Months & $1.04 \mathrm{E}+10$ & 11 & $9.44 \mathrm{E}+08$ & 777.774 & 2.81793 & $<0.05$ \\
\hline Error & 13352978 & 11 & 1213907 & & & \\
\hline Total & $1.04 \mathrm{E}+10$ & 23 & & & & \\
\hline \multicolumn{7}{|l|}{ Species diversity } \\
\hline Stations & 0.135 & 1 & 0.135 & 0.690219 & 4.844336 & NS \\
\hline Months & 3.471962 & 11 & 0.315633 & 1.613748 & 2.81793 & NS \\
\hline Error & 2.15149 & 11 & 0.19559 & & & \\
\hline Total & 5.758452 & 23 & & & & \\
\hline \multicolumn{7}{|l|}{ Species richness } \\
\hline Stations & 0.00329 & 1 & 0.00329 & 0.983397 & 4.844336 & NS \\
\hline Months & 0.034409 & 11 & 0.003128 & 0.934994 & 2.81793 & NS \\
\hline Error & 0.036801 & 11 & 0.003346 & & & \\
\hline Total & 0.074501 & 23 & & & & \\
\hline \multicolumn{7}{|l|}{ Species evenness } \\
\hline Stations & 0.00608 & 1 & 0.00608 & 1.186272 & 4.844336 & NS \\
\hline Months & 0.059654 & 11 & 0.005423 & 1.05807 & 2.81793 & NS \\
\hline Error & 0.05638 & 11 & 0.005125 & & & \\
\hline Total & 0.122114 & 23 & & & & \\
\hline
\end{tabular}

\section{NS - Non significant}

Table 3: Results of Two-way ANOVA for the zooplankton composition.

from 4,505 bits/ind. to 5,915 in station I and 4,590 bits/ind. to 5,928 bits/ind. in station II. Minimum zooplankton diversity was recorded in the month of December (2010) and maximum in the month of June (2011) in station I. In station II, the zooplankton diversity was recorded minimum in the month of December (2010) and maximum in the month of June (2011) (Table 4). The zooplankton diversity did not show significant variation between two stations (Table 3 ).

\section{Simpson richness}

The Simpson richness was ranged from 0.662 to 0.995 in station I and 0.665 to 0.998 in station II. The minimum species richness was recorded in the month of December (2010) and maximum in the month of June (2011) in station I. In station II, species richness was recorded minimum in the month of December (2010) and maximum in the month of June (2011) (Table 5). The species richness did not show significant variation between two stations (Table 3 ).

\section{Pielou's evenness ( $\left.J^{\prime}\right)$}

The Pielou's evenness $(\mathrm{J}$ ) was ranged from 0.590 to 0.952 in station I and 0.513 to 0.952 in station II. Minimum species evenness 
Citation: Thirunavukkarasu K, Soundarapandian P, Varadharajan D, Gunalan B (2013) Zooplankton Composition and Community Structure of Kottakudi and Nari Backwaters, South East of Tamil Nadu. J Environ Anal Toxicol 4: 200. doi: 10.4172/2161-0525.1000200

Page 4 of 7

\begin{tabular}{|c|c|c|c|c|c|}
\hline \multirow{2}{*}{ Seasons } & \multirow{2}{*}{ Months } & \multicolumn{2}{|c|}{2010} & \multicolumn{2}{c|}{2011} \\
\cline { 2 - 6 } & & Station I & Station II & Station I & Station II \\
\hline \multirow{3}{*}{ Post monsoon } & January & 4,690 & 4,686 & 4,690 & 4,678 \\
\cline { 2 - 6 } & February & 4,725 & 4,718 & 4,760 & 4,742 \\
\cline { 2 - 6 } Summer & March & 4,970 & 4,975 & 4,918 & 4,913 \\
\cline { 2 - 6 } & April & 5,138 & 5,297 & 5,190 & 5,239 \\
\cline { 2 - 6 } & May & 5,390 & 5,495 & 5,697 & 5,498 \\
\cline { 2 - 6 } & June & 5,580 & 5,610 & 5,915 & 5,928 \\
\hline Pre monsoon & July & 5,310 & 5,298 & 5,330 & 5,335 \\
\cline { 2 - 6 } & August & 5,190 & 5,112 & 5,113 & 5,213 \\
\cline { 2 - 6 } & September & 4,900 & 4,910 & 4,913 & 4,912 \\
\hline \multirow{3}{*}{ Monsoon } & October & 4,811 & 4,805 & 4,802 & 4,886 \\
\cline { 2 - 6 } & November & 4,590 & 4,610 & 4,603 & 4,615 \\
\hline & December & 4,505 & 4,590 & 4,573 & 4,613 \\
\hline
\end{tabular}

Table 4: Monthly variations of zooplankton population diversity (bits/ind) from January 2010 to December 2011

\begin{tabular}{|c|c|c|c|c|c|}
\hline \multirow{2}{*}{ Seasons } & \multirow{2}{*}{ Months } & \multicolumn{2}{|c|}{$\mathbf{2 0 1 0}$} & \multicolumn{2}{c|}{2011} \\
\cline { 3 - 6 } & & Station I & Station II & Station I & Station II \\
\hline \multirow{3}{*}{ Post monsoon } & January & 0.715 & 0.718 & 0.716 & 0.719 \\
\cline { 2 - 6 } & February & 0.892 & 0.894 & 0.895 & 0.892 \\
\cline { 2 - 6 } & March & 0.796 & 0.782 & 0.789 & 0.788 \\
\hline \multirow{3}{*}{ Summer } & April & 0.815 & 0.812 & 0.825 & 0.824 \\
\cline { 2 - 6 } & May & 0.948 & 0.945 & 0.952 & 0.952 \\
\cline { 2 - 6 } & June & 0.993 & 0.992 & 0.995 & 0.998 \\
\hline \multirow{3}{*}{ Monsoon } & July & 0.890 & 0.891 & 0.893 & 0.895 \\
\cline { 2 - 6 } & August & 0.873 & 0.875 & 0.860 & 0.872 \\
\cline { 2 - 6 } & September & 0.851 & 0.850 & 0.849 & 0.842 \\
\cline { 2 - 6 } & October & 0.825 & 0.823 & 0.816 & 0.812 \\
\hline & November & 0.793 & 0.795 & 0.796 & 0.798 \\
\hline
\end{tabular}

Table 5: Monthly variations of species richness from January 2010 to December 2011

was recorded in the month of December (2010) and maximum in the month of May (2011) in station I (Table 6). In station II, species evenness was recorded minimum in the month of December (2011) and maximum in the month of May (2011). The species evenness did not show significant variation between two stations (Table 3).

\section{Discussion}

Zooplankton in the present study consisted of a total of 88 (2010 \& 2011) forms in station I and 92 \& 89 forms (2010 \& 2011) in station II including larvae. The order of abundance of various groups are Pteropoda $<$ Decapoda $<$ Amphipoda $<$ Doliolida $<$ Cladocera $<$ Sagittoida $<$ Rotatoria $<$ Appendicularia $<$ Coelentrata $<$ Harpacticoidea $<$ Cyclopoida $<$ Larval forms $<$ Foraminifera $<$ Calanoida. Almost similar pattern of abundance was reported in Parangipettai coastal waters [16]. Population density of zooplankton was low during monsoon season due to the hydrographically washable environmental condition. The monsoon flow cause great depletion of zooplankton population density. Padmavathi and Goswami [17], Ananthan [18], Bhunia and Choudhury [19] had stated that the heavy rain changed the salinity, temperature and other environmental variable which in turn decreased the zooplankton density. Further, the higher population densities of zooplankton observed during summer were coincided with the peak of phytoplankton density. It is supported from the earlier observations of Govindasamy and Kannan [20] and Godhantaraman [21] from Parangipettai and Pitchavaram mangrove areas and Jegadeesan [22] in Coleroon estuary and Murugan and Ayyakkannu [23] from Uppanar

\begin{tabular}{|c|c|c|c|c|c|}
\hline \multirow{2}{*}{ Seasons } & \multirow{2}{*}{ Months } & \multicolumn{2}{|c|}{2010} & \multicolumn{2}{c|}{2011} \\
\cline { 3 - 6 } & & Station I & Station II & Station I & Station II \\
\hline \multirow{3}{*}{ Post monsoon } & January & 0.715 & 0.718 & 0.716 & 0.719 \\
\cline { 2 - 6 } & February & 0.892 & 0.894 & 0.895 & 0.892 \\
\cline { 2 - 6 } Summer & March & 0.796 & 0.782 & 0.789 & 0.788 \\
\cline { 2 - 6 } & April & 0.815 & 0.812 & 0.825 & 0.824 \\
\cline { 2 - 6 } & May & 0.948 & 0.945 & 0.952 & 0.952 \\
\cline { 2 - 6 } & June & 0.932 & 0.939 & 0.930 & 0.934 \\
\hline \multirow{3}{*}{ Pre monsoon } & July & 0.928 & 0.927 & 0.916 & 0.915 \\
\cline { 2 - 6 } & August & 0.893 & 0.892 & 0.898 & 0.893 \\
\cline { 2 - 6 } & September & 0.812 & 0.813 & 0.815 & 0.819 \\
\hline \multirow{3}{*}{ Monsoon } & October & 0.789 & 0.786 & 0.782 & 0.780 \\
\cline { 2 - 6 } & November & 0.615 & 0.618 & 0.613 & 0.620 \\
\hline & December & 0.590 & 0.591 & 0.596 & 0.513 \\
\hline
\end{tabular}

Table 6: Monthly variations of species evenness from January 2010 to December 2011.

backwater. Further, higher population density with more number of copepod species were also observed by Rajagopalan [24].

The higher zooplankton density was recorded during summer season, which might be due to stable environmental conditions. It prevailed during the season, and great neritic element presence from adjacent sea could also be contributed to the maximum density of zooplankton. Further, salinity is the key factor influencing zooplankton distribution and abundance in Goa waters [17]. Abundance of various zooplanktons in the coastal areas was being fluctuated in accordance with salinity regime. Among the various groups, calanoida formed a predominant group with a total number of 31 species. Also Acrocalanus gibber, A. gracilis and Paracalanus parvus were common forms found in both the stations, which might be due to their ability to adapt to the prevailing environmental conditions and also because of the continuous breeding behaviors of the species. Similar opinion was earlier given by Sampathkumar and Kannan [25], Sarkar et al. [26] Srinivasan and Santhanam [27], Kowenberg [28], Neelam Ramaiah and Vijayalakshmi Nair [29] and Biji [30].

There was a gradual increase in population density with the abundance of larval forms during summer, when optimal salinity was noticed. During monsoon season, the population density was comparatively low than in summer. This was due to the northeast monsoonal effect when heavy fresh water run-off caused a decline in population density. A recovery phase was noticed from March (postmonsoon) onwards. From these observations, it can be obvious that the summer season is favorable for macro-zooplankton production for both the stations of the present study. This was supported by the work of Srikrishnadhas, Sundaraj et al. [31] from Porto-Novo waters. The zooplankton plays a key role in the dynamics of aquatic ecosystems as their grazing limits in the standing crop of phytoplankton. Phytoplankton-zooplankton sequence forms the classical food chain in the aquatic environment. The zooplankton (secondary) production is significant as they occupy the second tropic tier between the phytoplankton (primary producer) and tertiary (carnivore production) tiers.

In the present study, copepods formed the dominant group in macro-zooplankton, both in species composition and richness. It constituted 80 to $90 \%$ of total macro-zooplankton population was well supported by Magdy and Nasser [32], who recorded 75\% in the Gulf of Aqaba, Red Sea, Egypt. Raghavan et al. [33] reported that copepods were predominant in macro-zooplankton population in the Arabian Sea. The copepods dominance in zooplankton were showed 
Citation: Thirunavukkarasu K, Soundarapandian P, Varadharajan D, Gunalan B (2013) Zooplankton Composition and Community Structure of Kottakudi and Nari Backwaters, South East of Tamil Nadu. J Environ Anal Toxicol 4: 200. doi: 10.4172/2161-0525.1000200

Page 5 of 7

\begin{tabular}{|c|c|c|c|c|c|c|c|c|c|c|c|}
\hline Parameters & Ra.fa. & Temp & Salin. & $\mathrm{pH}$ & DO & $\mathrm{NO}_{2}$ & $\mathrm{NO}_{3}$ & $\mathrm{NH}_{4}$ & IP & $\mathrm{SiO}_{3}$ & Pop. Den. \\
\hline Ra.fa. & 1 & & & & & & & & & & \\
\hline $\mathbf{T}$ & -0.226 & 1 & & & & & & & & & \\
\hline Salin. & $-0.879^{* *}$ & 0.493 & 1 & & & & & & & & \\
\hline $\mathrm{pH}$ & $-0.715^{\star}$ & 0.611 & $0.838^{*}$ & 1 & & & & & & & \\
\hline DO & -0.372 & $0.693^{*}$ & 0.476 & $0.603^{*}$ & 1 & & & & & & \\
\hline $\mathrm{NO}_{2}$ & $0.561^{*}$ & $-0.725^{\star *}$ & $-0.625^{*}$ & $-0.739^{* *}$ & -0.950 & 1 & & & & & \\
\hline $\mathrm{NO}_{3}$ & 0.427 & $-0.727^{\star \star}$ & $-0.492^{*}$ & $-0.674^{\star *}$ & -0.934 & 0.973 & 1 & & & & \\
\hline $\mathrm{NH}_{3}$ & $0.616^{* *}$ & $-0.622^{* *}$ & $-0.622^{* *}$ & $-0.755^{* *}$ & -0.879 & 0.965 & 0.948 & 1 & & & \\
\hline IP & $0.525^{*}$ & -0.812 & $-0.610^{*}$ & $-0.799^{* *}$ & -0.891 & 0.957 & 0.947 & 0.910 & 1 & & \\
\hline $\mathrm{SiO}_{3}$ & $0.663^{* *}$ & $-0.619^{* *}$ & $-0.693^{* *}$ & -0.711 & -0.921 & 0.953 & 0.908 & 0.922 & 0.899 & 1 & \\
\hline Pop. Den. & $-0.579^{* *}$ & $0.571^{\star *}$ & $0.671^{* \star}$ & $0.640^{* *}$ & 0.822 & -0.807 & -0.683 & -0.734 & -0.723 & -0.844 & 1 \\
\hline
\end{tabular}

${ }^{*}$ Correlation is significant at $5 \%$ level $(P<0.05)$

${ }^{* *}$ Correlation is significant at $1 \%$ level $(\mathrm{P}<0.01)$

Table 7: Correlation ( $r$ ) values between physico-chemical parameters, biological parameters and zooplanktons for station-I.

\begin{tabular}{|c|c|c|c|c|c|c|c|c|c|c|c|}
\hline Parameters & Ra.fa. & $\mathbf{T}$ & Salin. & $\mathrm{pH}$ & DO & $\mathrm{NO}_{4}$ & $\mathrm{NO}_{3}$ & $\mathrm{NH}_{4}$ & IP & $\mathrm{SiO}_{3}$ & Pop. Den. \\
\hline Ra.fa. & 1 & & & & & & & & & & \\
\hline $\mathbf{T}$ & -0.542 & 1 & & & & & & & & & \\
\hline Salin. & $-0.766^{*}$ & $0.798^{*}$ & 1 & & & & & & & & \\
\hline $\mathrm{pH}$ & $-0.808^{* *}$ & $0.720^{*}$ & $0.970^{* *}$ & 1 & & & & & & & \\
\hline DO & -0.350 & $0.780^{* *}$ & $0.639^{*}$ & 0.541 & 1 & & & & & & \\
\hline $\mathrm{NO}_{2}$ & $0.582^{*}$ & -0.858 & $-0.724^{* *}$ & $-0.679^{* *}$ & -0.930 & 1 & & & & & \\
\hline $\mathrm{NO}_{3}$ & 0.428 & -0.872 & $-0.638^{* *}$ & $-0.579^{*}$ & -0.925 & 0.962 & 1 & & & & \\
\hline $\mathrm{NH}_{4}$ & $0.616^{* *}$ & -0.844 & $-0.729^{\star *}$ & $-0.701^{* *}$ & -0.862 & 0.968 & 0.949 & 1 & & & \\
\hline IP & $0.525^{* *}$ & -0.952 & $-0.706^{* *}$ & $-0.642^{* *}$ & -0.849 & 0.930 & 0.945 & 0.910 & 1 & & \\
\hline $\mathrm{SiO}_{3}$ & $0.679^{* *}$ & -0.873 & -0.804 & -0.738 & -0.906 & 0.959 & 0.908 & 0.923 & 0.908 & 1 & \\
\hline Pop. Den. & $-0.576^{* *}$ & $0.665^{\star *}$ & 0.759 & 0.695 & 0.826 & -0.821 & -0.704 & -0.749 & -0.732 & -0.848 & 1 \\
\hline
\end{tabular}

${ }^{*}$ Correlation is significant at $5 \%$ level $(P<0.05)$

** Correlation is significant at $1 \%$ level $(P<0.01)$

Table 8: Correlation $(r)$ values between physico-chemical parameters, biological parameters and zooplanktons for station-II.

in the central west coast of India, Vijayalakshmi et al. [34] in near shore waters of zooplankton in a coastal upwelling in New Zealand central waters [35]. The dominance of copepods, among different other macro-zooplankton groups, in most of the places including the present study suggests that copepods probably show successful adaptation to any type of aquatic environment than any other group of zooplankton. Understanding of copepods fauna is, therefore, important for management and protection of biological resources in the coastal waters. The diverse marine plankton has been influenced by the long and short term (geological, climatic, hydrological) natural and anthropogenic processes [36]. Investigation on the species composition, population density and community structure of the zooplankton is necessary to assess the potential fishery resource of any given area [37]. Marine copepods are natural feed, which can act as alternatives or supplements to Artemia nauplii [38-41]. Copepods were found to be numerically abundant throughout the study period at both the stations. Similar copepods abundance was also recorded earlier by Sreekumaran et al. [42] in western Bay of Bengal, Abidi et al. [43] from Akarpati (Navapur) coastal water, Gajbhiye and Desai [44] in polluted and unpolluted regions of Bombay waters, Anbazhagan [45] in Kodiakarai waters and Vijayakumar and Sarma [46] from Visakhapatnam harbor water.

The abundance of this group steadily increased in both the stations from November to May with raising trend of salinity. With the onset of southwest monsoon (July-October), salinity dropped and the population density also declined $[1,19]$. The important factors that controlled the distribution of calanoida were rainfall and salinity as suggested by Bijoy and Abdul [47], Neelam Ramaiah et al. [48]. Calanoida are the primary consumers of phytoplankton and principal food prey of larval and juvenile fishes, making up the base of pelagic food chains [49]. Calanoida dominated in the zooplankton community in abundance throughout the year, forming $30-35 \%$ of total zooplankton composition [50]. In the present study also calanoids were the dominant copepods for both the stations followed by cyclopoids and harpacticoids. Tintinoids showed a wide range of salinity tolerance and they have recorded high during summer might be due to influence of neritic waters. These results are in agreement with the previous findings of Chandran and Damodara et al. [51,52] from Vellar estuary and Jegadeesan [22] from Coleroon estuary. The meroplankton organisms such as bivalve veliger, gastropod veliger and copepod nauplii were commonly available for both the station. It is already reported in Point Calimere coastal waters Sundharesan [53]. The fish were also found to be common for both the stations indicated that the coastal ecosystem serves as breeding and nursery grounds for a variety of fish. These findings are agreement with the reports of Chandrasekaran and Natarajan [54].

Maximum species diversity of zooplankton was recorded during the month of June of summer season for both the stations. The high values of zooplankton species diversity were found to be associated with the high zooplankton density that also indicated the stable high salinity and phytoplankton density. The low species diversity was observed during monsoon season could be attributed to heavy rainfall influx and low salinity. Rajkumar [21] Govindasamy and Kannan [40] have obtained similar values from Pitchavaram mangroves. The maximum evenness 
Citation: Thirunavukkarasu K, Soundarapandian P, Varadharajan D, Gunalan B (2013) Zooplankton Composition and Community Structure of Kottakudi and Nari Backwaters, South East of Tamil Nadu. J Environ Anal Toxicol 4: 200. doi: 10.4172/2161-0525.1000200

Page 6 of 7

values were recorded during summer season and the minimum values during monsoon season. Similar observations were already made by Neelam Ramaiah andVijayalakshmi Nair [29] from Vellar estuary and from Uppanar estuary by Murugan and Ayyakkannu [23]. In general, species diversity index coincide with species richness and diversity index with increasing richness of species. During monsoon season, the freshwater flow played a key role in altering the estuary environment and resulted in reduction of species, thereby decreasing the diversity index. The results of Analysis of Variance (ANOVA) for the difference in zooplankton distribution between the stations are significant at $0.05 \%$ level. The results of the present study showed that a combination of factors influence the zooplankton distribution and abundance in estuary. Among the various factors examined, abrupt change in salinity caused by rainfall can be considered as the most important water quality parameter which affects zooplankton abundance as reported previously by many workers Watanabe et al. [38], Rajkumar [39-41]. The results of the present study showed that a combination of factors influence the zooplankton distribution and abundance in estuary. Among the various factors examined, abrupt change in salinity caused by rainfall can be considered as the most important water quality parameter which affects zooplankton abundance.

\section{References}

1. Banse K (1995) Zooplankton: Pivotal role in the control of ocean production. Indian J Mar Sci 52: 265-277.

2. Cook RB, Bunker A, Hay S, Hirst AG, Speirs DC (2007) Studied the naupliar development times and survival of the copepods Calanus helgolandicus and Calanus finmarchicus in relation to food and temperature. J Plankton Res 29 : 757-767.

3. Andrew ME (2001) Adding detritus to a nutrient-phytoplankton-zooplankton model: A dynamical-systems approach. J Plankton Res 2: 389-413.

4. Stottrup JG (2000) The elusive copepods: Their production and suitability in marine aquaculture. Aquacult Res 31: 703-711.

5. Fulton RS (1984) Distribution and community structure of estuarine copepods. Estu 7: 38-50.

6. Mishra S, Panigrahy RC (1996) Copepods of Bahuda estuary (Orissa), East coast of India. Indian J Mar Sci 19: 120-124.

7. Davis CC (1957) The marine and freshwater plankton. Michigan State University Press. p 562.

8. Kasturirangan LR (1963)A key for the identification of the more common planktonic copepoda of the Indian coastal waters. Publication No. CSIR Pup 1-87.

9. Newell GE, Newell RC (1963) Marine plankton-A practical guide. 5th edn. Hutchinson and Company (Publishers) Ltd, London. 244.

10. Deboyd LS, Johnson KB, Rome FAO (1977) A guide to marine coastal plankton and marine invertebrate larvae. Kendal/Hunt Publishing Company, USA. 161.

11. Wimpenny RS (1966) The plankton of the Sea. Faber and Faber Ltd, London 426

12. Todd CD, Laveract MS (1991) Coastal marine zooplankton-A practical manual for students. Cambridge University Press 106

13. Perumal P, Sampathkumar P, Santhanam P (1998) Zooplankton of Parangipettai coast waters. Monogr. Series, Vol. I. UGC-SAP, CAS in Marine Biology, Annamalai University, Parangipettai. p 31.

14. Shannon CE, Wiener W (1949) The mathematical theory of communication University of Illionis Press, Urbana 1-117.

15. Pielous EC (1966) The measurement of diversity in different types of biological collections. J Theor Biol 13: 131-144.

16. Santhanam P, Perumal P (2003) Diversity of zooplankton in Parangipetta coastal waters, southeast coast of India. J Mar Biol Ass India 45(2): 144-151.

17. Padmavathi G, Goswami SC (1996) Zooplankton ecology in the Mandovi-Zuari estuarine system of Goa, West coast of India. Indian J Mar Sci 25: 268-273.

18. Ananthan G (1991) Hydrobiology of Parangipettai and Cuddalore marine environs with special reference to heavy metal pollution. M.Phil., Thesis,
Annamalai University, India. pp 1-57.

19. Bhunia M, Choudhury A (1982) Some ecological consideration for zooplankton production in Chemagari creek, Sagar island (South), Sunderbans. MahasagarBull Natl Oceanogr 15: 247-252.

20. Govindasamy C, Kannan L (1996) Rotifers of Pichavaram mangroves, Southeast coast of India. Indian Hydrobiol 1: 69-76.

21. Godhantaraman N (1994) Studied the delayed hydrobiological account of 35 species of rotifers belonging to 17 genera in Pichavaram mangroves (South India). Ciencias Mar, 20(3): 371-391.

22. Jegadeesan $P$ (1986) Studies on the environmental inventory of the marine zone of Coleroon estuary and inshore waters of Pazhayaru, Southeast coast of India. Ph.D., Thesis, Annamalai University, India. pp 1-277.

23. Murugan A, Ayyakkannu K (1991) Ecology of Uppanar backwaters. Cuddalore, I. Physico-chemical parameters. Mahasagar-Bull Natl Inst Oceanogr 24: 31-38.

24. Rajagopalan MS, Thomas PA, Mathew KJ, Naomi TS, Kaladharan P, et al (1992) Productivity of the Arabian Sea along the Southwest coast of India. Bull Cent Mar Fish Res Inst 45: 9-37.

25. Sampathkumar P, Kannan L (1998) Seasonal variations in physico-chemical characteristics in the Tranquebar-Nagapattinam region, Southeast coast of India. Poll Res 17: 397-402.

26. Sarkar SK, Sing BN, Choudhury R (1986) Seasonal distribution of copepods in the Hooghly estuary, Northern Bay of Bengal. Indian J Mar Sci 15: 177-180.

27. Srinivasan A, Santhanam R (1991) Tidal and seasonal variation in zooplankton of Pullavazhi brackishwater, southeast coast of India. Indian J Mar Sci 20: 182-186.

28. Kowenberg J HM (1993) Copepod distribution in relation to seasonal hydrographic and spatial structure in the North-Western Mediterranean (Gulf du Lion). Est Coast Shelf Sci 38: 69-90.

29. Neelam Ramaiah, Vijayalakshmi Nair N (1997) Distribution and abundance of copepods in the pollution gradient zones of Bombay harbour-Thane creekBasin creek, West Coast of India. Indian J Mar Sci 26: 20-25

30. Biji KT (2003) Ecologyical and experimental studies on zooplankton of inshore water of Parangipettai, Southeast coast of India. M.Phil., Thesis, Annamalai University, India. pp 1-113.

31. Srikrishnadhas B, Sundaraj V, Ramamoorthi K (1993) Zoopalnkton of Porto Novo coastal zone with special reference to invertebrate larvae. J Mar Bio Ass India 35: 141-144.

32. Magdy TK, Nasser S (1997) Abundance and diversity of surface zooplankton in the Gulf of Aqaba, Red Sea, Egypt. J Plankton Res 19: 927-936.

33. Raghavan SV, Selvakumar RA, Rao TSS (1982) Studies on zooplankton from Arabian Sea off the South-Central West coast of India. Indian J Mar Sci 11 70-74.

34. Desai BN, Kumari LK, Gajbhiye SN, Nair VR, National Inst., of Oceanography (1983) Biomass and composition of zooplankton in near shore waters of Thal, Maharashtra. Indian J Mar Sci 12: 160-165.

35. Foster BA, Battaerd WR (1985) Distribution of zooplankton in a coastal upwelling in New Zealand. New Zealand J Mar Fresh Res 79: 213-226.

36. Kovalev AV, Skryabin VA, Zagorodnyaya YA, Bingel F, Kideys AE, et al. (1999) The Black Sea zooplankton: Composition, spatioal/temporal distribution and history of investigations. Tr J Zoo 23: 195-209.

37. Tiwari LR, Nair VR (1991) Contribution of zooplankton to the fishery of Dharamtar creek, adjoining Bomboy harbour. J Indian Fish Ass 21: 15-19.

38. Watanabe T, Kitajima C, Fujita S (1983) Nutritional values of live organisms used in Japan for mass propagation of fish-A review. Aquacul 34: 115-143.

39. Rajkumar M (2003) Hydrobiological studies in Pitchavaram mangroves (Southeast coast of India) with references to plankton. M. Phil., Thesis, Annamalai University, India. pp 1-125.

40. Rajkumar M (2006) Studies on ecology, experimental biology and live feed suitability of Copepods, Acartia erythraea Giesbrecht and Oithona brevicornis Giesbrecht from Coleroon Estuary (India). Ph.D., Thesis, Annamalai University, India. pp1-320.

41. Rajkumar M, Santhanam P, Perumal P (2004) Laboratory culture of calanoid copepod, Acartia clause Giesbrecht. Appl Fish Aqua 4: 5-8. 
Citation: Thirunavukkarasu K, Soundarapandian P, Varadharajan D, Gunalan B (2013) Zooplankton Composition and Community Structure of Kottakudi and Nari Backwaters, South East of Tamil Nadu. J Environ Anal Toxicol 4: 200. doi: 10.4172/2161-0525.1000200

42. Nair SRS, Nair VR, Achuthankutty CT, Madhuupratap M (1981) Zooplankton composition and diversity in Western Bay of Bengal. J Plankton Res 3:493-508.

43. Abidi SAH, Desai BN, Jiyalal Ram (1983) Studies on the hydrography and plankton off Akarapati near Navapur, West coast of India during February March. Mahasagar-Bull Natl Inst Oceanogr 16(1): 91-94.

44. Gajbhiye SN, Desai BN (1981) Zooplankton variability in polluted and unpolluted waters of Bombay. Mahasagar 14: 173-182.

45. Anbazhagan P (1988) Hydrobiology and benthic ecology of Kodiakkarai coastal sanctuary (Southeast coast of India). Ph.D., Thesis, Annamalai University, India. pp 1

46. Vijayakumar GS, Sarma VV (1998) Zooplankton studies in Visakhapatnam harbour and near shore waters, East coast of India. Indian J Mar Sci 17: 75-77.

47. Bijoy Nandan S, Abdul Azis PK (1994) Organic matter of sediments from the retting the non-retting areas of Kadinamkulam estuary, Southeast coast of India. Indian J Mar Sci 25: 25-28.

48. Ramaiah N, Ramaiah N (1998) Phytoplankton characteristics in a polluted Bombay harbour-Thana-Bassein creek estuarine complex. Indian J Mar Sc 27: 281-285
49. Huys R, Boxshall GA (1991) Copepod Evolution. The Ray Society, London 159 $1-448$.

50. Mwaluma J, Melckzedeck O, Kamau J, Wawiye P (2003) composition, abundance and seasonality of zooplankton in Mida Creek, Kenya. Western India Ocean J Mar Sci 2: 147-155.

51. Chandran R (1985) Seasonal and tidal variations of phytoplankton in the gradient zone of Vellar estuary. Mahasagar- Bull Natl Inst Oceanogr 18: 37-48.

52. Damodara NW, Santhanam R, Krishnamurthy K, Natrajan R (1997) The species biomass and the seasonal composition of tintinnida (Protozoa:Ciliate) Proc Sym Warm Water Zoopl Spl Publ UNESCO/NIO 520-527.

53. Sundharesan T (2008) Diversity of marine plankton in point calimere coastal water (south east coast of India) M.Phil., Thesis, Annamalai University, India 1- 92

54. Chandrasekaran VS, Natarajan R (1993) Mullet seed resources of Pichavaram mangrove, southeast coast India. J Mar Biol Ass India 35: 167-174. 